\title{
CHROMATOGRAPHIC DETERMINATION OF TRIACYLGLYCEROL COMPOSITION OF INTERESTERIFIED LIQUID VEGETABLE OILS
}

\author{
N. Sytnik, I. Demidov, V. Mazaeva, V. Golodnyak \\ Ukrainian Research Institute of Oils and Fats of \\ National Academy of Agrarian Sciences of Ukraine
}

\begin{tabular}{|c|c|}
\hline Кеу & $T$ \\
\hline $\begin{array}{l}\text { Fat } \\
\text { Interesterification } \\
\text { Gas-liquid } \\
\text { chromatography } \\
\text { Fatty acid composition } \\
\text { Triacylglycerol } \\
\text { composition }\end{array}$ & $\begin{array}{l}\text { The article presents the results of research on the development } \\
\text { of a method for the determination of interesterified oils and fats } \\
\text { based on the experimental determination of the acylglycerol } \\
\text { composition of primary and interesterified fatty raw materials, } \\
\text { as well as theoretical calculations of the statistically equilibrium } \\
\text { acylglycerol composition and statistical processing of the } \\
\text { obtained data. On the basis of the obtained results, a criterion }\end{array}$ \\
\hline $\begin{array}{l}\quad \text { Article history: } \\
\text { Received 06.05.2017 } \\
\text { Received in revised form } \\
27.05 .2017 \\
\text { Accepted } 14.06 .2017\end{array}$ & $\begin{array}{l}\text { for identifying interesterified oils was determined. The method } \\
\text { of measurement is developed, which makes it possible to } \\
\text { distinguish between interesterified oils from unperpetrified } \\
\text { ones, as well as to evaluate the characteristics of the error and } \\
\text { uncertainty of the measurement methodology. The chroma- }\end{array}$ \\
\hline $\begin{array}{l}\text { Corresponding author: } \\
\text { N. Sytnik } \\
\text { E-mail: } \\
\text { npnuht@ukr.net }\end{array}$ & $\begin{array}{l}\text { tographic methods of measuring fatty acid and triacylglycerol } \\
\text { composition of experimental oils are used. The algorithm and } \\
\text { the methodology of preparation of the initial raw material for } \\
\text { experimental interesterification have been developed, as well as } \\
\text { experimental researches have been carried out on the choice of } \\
\text { regimes and conditions for conducting oil interestereification } \\
\text { for the purpose of the methodology. }\end{array}$ \\
\hline
\end{tabular}

DOI: $10.24263 / 2225-2924-2017-23-4-19$

\section{ХРОМАТОГРАФІЧНЕ ВИЗНАЧЕННЯ ТРИАЦИЛГЛІЦЕРОЛЬНОГО СКЛАДУ ПЕРЕЕТЕРИФІКОВАНИХ РІДКИХ РОСЛИННИХ ОЛІЙ}

\author{
Н.С. Ситнік, І.М. Демидов, В.С. Мазаєва, В.О. Голодняк \\ Украӥнський науково-дослідний інститут олій та жирів \\ Національної академії аграрних наук України
}

У статті представлено результати досліджень з розробки методики визначення переетерифікованих олій $і$ жирів, щео базується на експериментальному визначенні ацилглічерольного складу початкової та переетерифікованої жирової сировини, а також теоретичних розрахунках статистично рівноважного ацилглічерольного складу й статистичній обробиі одержсаних даних. На підставі одержаних результатів визначено критерій ідентифікаиії переетерифікованих олій. Розроблено методику виконання вимірювань, яка дає змогу відрізнити переетерифіковані олії від непереетерифікованих, а також оцінити 
характеристики похибки та невизначеності методики виконання вимірювань. Застосовано хроматографічні методи вимірювання жирнокислотного та триацилглічерольного складу дослідних олій. Розроблено алгоритм і методику підготовки початкової сировини до дослідного переетерифікування, а також виконано експериментальні дослідження вибору режимів $і$ умов проведення переетерифікування олій для иілей методики.

Ключові слова: жир, переетерифікування, газорідинна хроматографія, жирнокислотний склад, триацилглічерольний склад.

Постановка проблеми. Переетерифікування являє собою процес, під час якого відбувається перегрупування жирних кислот всередині молекул і між молекулами ацилгліцеролів одного жиру або сумішей різних жирів. Цей процес $є$ одним із найбільш поширених методів модифікації олій і жирів, завдяки якому здійснюється виробництво жировмісних продуктів із потрібними фізико-хімічними й органолептичними властивостями, обмеженим вмістом транс-ізомерів жирних кислот, продукції з підвищеною якістю [1-3]. Так, додавання переетерифікованих жирів до жирової основи маргарину істотно покращує технологічні характеристики продукту, дає змогу на $15 \%$ знизити питому витрату гідрованих жирів на виробництво маргаринової продукції та підвищити іiі харчову цінність, стабільність при зберіганні та використанні [4]. Сьогодні приділяється багато уваги контролю якості та безпечності харчових продуктів. Особлива увага приділяється сучасним високоточним методам дослідження, зокрема, з використанням газорідинної хроматографії [5; 6]

У сучасних умовах актуальним $\epsilon$ завдання унеможливити ввезення переетерифікованих жирів (олій) на митну територію України під виглядом натуральних жирів (олій), тобто без зміни хімічного складу. Основними методами контролю $є$ порівняння температур плавлення та визначення відсоткового вмісту твердих триацилгліцеролів (ТТГ) [4]. Але жирнокислотний склад початкового та переетерифікованого жирів не відрізняється, а для деяких жирів дуже мало відрізняються і їхні фізико-хімічні властивості, отже цей метод не $\epsilon$ досконалим у даному випадку. Тому більш надійним способом відрізнити переетерифікований жир від непереетерифікованого може стати порівняння їх ацилгліцерольного складу, зміна якого в результаті переетерифікування може супроводжуватися як зростанням, так і зниженням температури плавлення.

У [7] досліджено ацилгліцерольний склад шести зразків олій: соняшникової, соняшникової високоолеїнової, соєвої, ріпакової, пальмової олії та пальмового олеїну. Визначено, що ацилгліцерольний склад непереетерифікованих олій суттєво відрізняється від статистично рівноважного ацилгліцерольного складу, наближення до якого спостерігається під час переетерифікування. Одержані дані свідчать про принципову можливість розробки методики ідентифікації переетерифікованих олій і жирів, заснованої на порівнянні триацилгліцерольного складу початкових та переетерифікованих зразків.

У [8] досліджено зміну триацилгліцерольного складу пальмового олеїну початкового, переетерифікованого та переетерифікованого повторно. Визначено, що зміна триацилгліцерольного складу пальмового олеїну відбувається у значно більшій мірі після першого переетерифікування, ніж після другого. 
У результаті переетерифікування олій і жирів відбувається наближення триацилгліцерольного складу до статистично рівноважного, при цьому статистично рівноважний склад не змінюється під час наступних процесів переетерифікування. Дане твердження розглянуто та доведено для пальмової олії [5]. Це стало підставою для дослідження інших видів жирової сировини 3 іншим жирнокислотним складом.

Теоретичні уявлення щодо методу. Кількісний склад триацилгліцеролів, які утворюються в процесі переетерифікування, а також розподілення жирних кислот між триацилгліцеролами поступово наближується до статистично розрахованого [1]. Таким чином, якщо молекулярний склад жирних кислот у переетерифікованому жирі відомий, то склад триацилгліцеролів, утворених при досягненні рівноваги реакції статистичного переетерифікування, може бути визначений математичним шляхом. Під час переетерифікування жирових сумішей для одержання жирів із заданими властивостями, керуючись співвідношенням:

$$
(a+b+c+d++\ldots+\ldots+p)^{3}=1,
$$

де $a, b, c, d \ldots p-$ молярні частки жирних кислот, що входять до складу триацилгліцеролів даного жиру, можна розрахувати рівноважний триацилгліцерольний склад, виходячи 3 жирнокислотного складу сумішей, які після переетерифікування утворять жири з бажаним триацилгліцерольним складом, температурою плавлення і твердістю, що, у свою чергу, має винятково важливе практичне значення для виробництва жирів з заданими фізико-хімічними властивостями. Рівноважний триацилгліцерольний склад олій не змінюється при їх наступних переетерифікуваннях та, теоретично, може бути розрахований при відомому жирнокислотному складі за допомогою формули (1).

Спочатку визначають жирнокислотний склад олії та іiі ТАГ-склад за допомогою газової хроматографії, потім виконується процес переетерифікування олії, після чого знову визначається іiі ТАГ-склад. Виконується оцінювання різниці в ацилгліцерольному складі початкової та переетерифікованої проб і на підставі цього роблять висновок щодо походження зразка олії. Якщо після наступних переетерифікувань ТАГ-склад не змінюється, це $є$ підставою вважати, що початкова олія була переетерифікованою. Результати вимірювань вмісту ТАГ після першого та другого переетерифікування виконувалися як незалежні вимірювання. Тому для зіставлення результатів вимірювань цілком можливо застосувати правило розрахунку загальної похибки для незалежних випробовувань, які мають похибки вимірювань, відповідно, $\Delta_{1}$ та $\Delta_{2}$ :

$$
\Delta=\sqrt{\Delta_{1}^{2}+\Delta_{2}^{2}} .
$$

Оскільки вимірювання виконувалися за однією і тією ж методикою, то виходячи з цього обидва результати мають одну і ту ж похибку:

$$
\Delta_{M}=\Delta_{1}+\Delta_{2},
$$

де $\Delta_{\mu}$ - похибка вимірювань методики вимірювань для кожного окремого ТАГ відповідно до діапазону вимірювань. Тоді $\Delta=1,41 \cdot \Delta_{\mu}$. 
На підставі того, що для переетерифікованої олії друге переетерифікування не змінює триацилгліцерольний склад, критерієм ідентифікації переетерифікованої олії є умова знаходження результатів обох вимірювань у межах похибки двох незалежних вимірювань, тобто якщо виконується співвідношення

$$
-\Delta<\left(x_{1}-x_{2}\right)<\Delta,
$$

то початкова олія $є$ переетерифікованою. В разі, якщо це співвідношення не виконується - початкова олія не $\epsilon$ переетерефікованою.

Мета дослідження: розробки методики визначення переетерифікованих олій і жирів, що базується на експериментальному визначенні ацилгліцерольного складу початкової та переетерифікованої жирової сировини, а також теоретичних розрахунках статистично рівноважного ацилгліцерольного складу й статистичній обробці одержаних даних

Матеріали та методи. У дослідженні використано такі модельні об'єкти: олія соняшникова низькоолеїнова, олія соняшникова високоолеїнова, олія соєва, олія ріпакова. Дослідне переетерифікування олій проведено у лабораторних умовах за температури $115^{\circ} \mathrm{C}$, тривалість - 1,5 год в умовах вакууму за наявності каталізатора (натрію метилат у кількості 0,235\%). Триацилгліцерольний склад олій визначено 3 використанням газового хроматографа HewlettPackard HP-6890. Вміст кожного компонента визначали як відсоткове відношення площини піку індивідуального триацилгліцеролу до сумарної площини всіх триацилгліцеролів.

Результати і обговорення. На підставі отриманих результатів вимірювань проведено розрахунки похибки вимірювань і побудовано графічні залежності, що являють собою співвідношення розходження та похибки вимірювань. Результати досліджень наведено на рис. $1-4$, де $x_{0}$ - триацилгліцерольний склад початкової жирової сировини, $x_{1}$ - триацилгліцерольний склад жирової сировини після першого переетерифікування, $x_{2}$ - після повторного переетерифікування. На представлених графічних залежностях вісь абсцис представляє триацилгліцероли: 1 - PPS, 2 - POP, 3 - PLP, 4 - POS, 5 - PLS, 6 POO, 7 - PLO, 8 - PLL, 9 - PLLn, 10 - OOO+SLS, 11 - SLO, 12 - OOL, 13 - SLL, 14 - SOO, 15 - OLL, 16 - LLL, 17 - LLLn. У наведених вище триацилгліцеролах наявні залишки таких жирних кислот: P - пальмітинової, $\mathrm{S}$ - стеаринової, O — олеїнової, L —лінолевої, Ln — ліноленової.

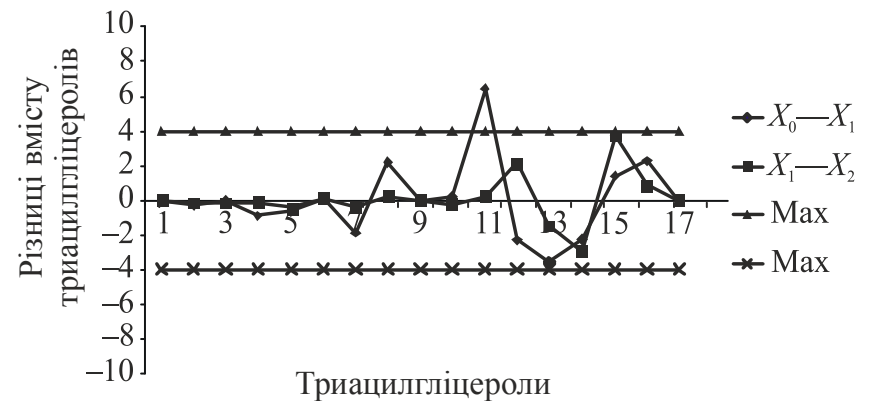

Рис. 1. Розходження і похибка вимірювання триацилгліцерольного складу соняшникової олії низькоолеїнової 
Як видно з рис. 1, різниця у триацилгліцерольному складі початкової соняшникової олії $\left(x_{0}\right)$ та після першого переетерифікування $\left(x_{1}\right)$ перевищує різницю у триацилгліцерольному складі між олією після першого $\left(x_{1}\right)$ та другого $\left(x_{2}\right)$ переетерифікування.

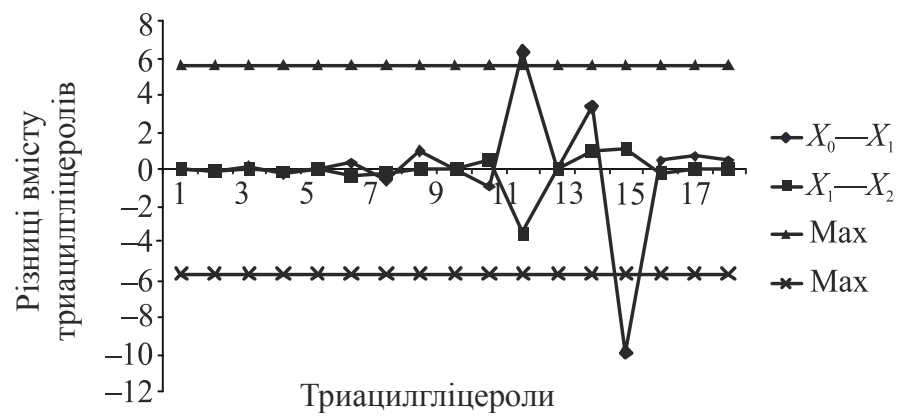

Рис.2. Розходження і похибка вимірювання триацилгліцерольного складу олії соняшникової високоолеїнової

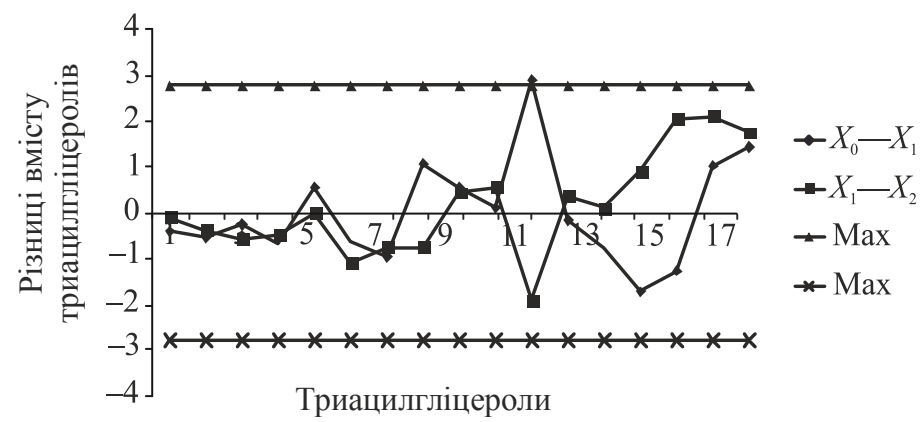

Рис. 3. Розходження і похибка вимірювання триацилгліцерольного складу соєвої олії

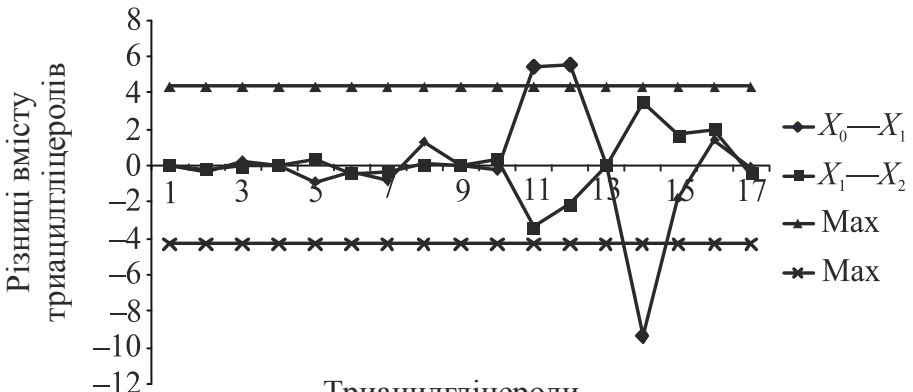

Триацилгліцероли

Рис. 4. Розходження і похибка вимірювання триацилгліцерольного складу ріпакової олії

За даними, наведеними на рис. $2-4$, також підтверджено той факт, що у випадку більшості триацилгліцеролів дослідних олій спостерігається зміна триацилгліцерольного складу в більшій мірі після першого переетерифікування, ніж після повторного, тобто величина різниць концентра- 
цій триацилгліцеролів між початковим зразком $\left(x_{0}\right)$ та переетерифікованим вперше $\left(x_{1}\right)$ є більшою, ніж між зразком, переетерифікованим вперше $\left(x_{1}\right)$ та повторно $\left(x_{2}\right)$.

Попередні дослідження [5; 8], а також наведені на рис. $1-4$ результати $\epsilon$ експериментальною основою розробленої методики, заснованої на порівнянні триацилгліцерольного складу початкових, переетерифікованих і повторно переетерифікованих олій та жирів.

Одержана сумарна максимальна похибка вимірювань, а також похибка вимірювання вмісту кожного триацилгліцеролу, що залежить від величини його концентрації, свідчить, що різниця триацилгліцерольного складу між початковою та переетерифікованою оліями виходить за межі загальної похибки, а різниця триацилгліцерольного складу між олією після першого та другого переетерифікування знаходиться в їі межах. Обробку даних виконано за методикою знаходження значення похибки по одній групі даних згідно 3 ГОСТ 8.207-76. Кількість паралельних вимірювань обрано згідно з рекомендацій $[9 ; 10]$. Таким чином, експериментально підтверджено можливість ідентифікації переетерифікованих олій та жирів за співвідношенням (4).

\section{Висновки}

1. Одержані експериментальні дані свідчать про те, що різниці вмісту триацилгліцеролів між початковими зразками олій і після першого переетерифікування, а також між зразками після першого та другого переетерифікування відрізняються майже на порядок.

2. Під час порівняння триацилгліцерольного складу початкових і вперше переетерифікованих зразків спостерігається вихід різниць вмісту триацилгліцеролів за межі похибки вимірювання, а під час повторного переетерифікування зразків зміна триацилгліцерольного складу відбувається у межах похибки.

3. На підставі результатів досліджень експериментально підтверджено можливість ідентифікації переетерифікованих олій і жирів. Методика надає можливість визначити, чи є жир, представлений на аналіз, переетерифікованим.

\section{Лiтература}

1. Гринберг Г. Модифицированные жиры [Текст] / Г. Гринберг, Г. Щепаньская. Москва : Пищевая промышленность, 1973. - $105 \mathrm{c}$.

2. Valenzuela Alfonso, Morgado Nora Trans fatty acid isomers in human health and in the food industry // Biol. Res. - 1999. - Vol. 32, № 4. - P. 273-287.

3. Технология переработки жиров / Н.С. Арутюнян, Е.П. Корнена, и др. Под ред. проф. Н.С. Арутюняна. - 3-е изд. - Москва : Пищепромиздат, 1999. — 452 с.

4. Технологія модифікованих жирів [Текст] / [Ф.Ф. Гладкий, В.К. Тимченко, I.М. Демидов та ін.].-Харків : Підручник НТУ «ХПІ», 2014. — 214 с.

5. Рожнов М.С. Методы и подходы к идентификации пищевых продуктов [Текст] / М.С. Рожнов, Д.Н. Мельник, В.А. Голодняк, И.Н. Демидов // Масложировой комплекс. Днепропетровск : ИА «Эксперт-Агро». — 2013. — № 4(43). — С. 43 - 46.

6. Левчук I.B. Сучасні методи ідентифікації олій та жирів у технохімконтролі жиропереробного виробництва [Текст] / І.В. Левчук, В.А.Кіщенко, В.К. Тимченко, К.В. Куниця // Вісник НТУ «ХПІ». — Харків : НТУ «ХПІ». — 2015. — № 14(1123). - С. 71-78. 
7. Демидов И.Н. Ацилглицерольный состав жиров и реакция переэтерификации [Текст] / И.Н. Демидов, В.С. Мазаева, Н.С. Сытник, В.А. Голодняк, В.А. Кищенко, О.В. Голубец // Масложировой комплекс. - Днепропетровск : ИА «Эксперт-Агро». - 2013. № 4(43). - С. 28-29.

8. Голодняк B.A. Определение активности катализатора химической переэтерификации жиров [Текст] / В.А. Голодняк, И.Н. Демидов, В.С. Мазаева, Н.С. Сытник, П.Ф. Петик // Оралдын гылым жаршысы. - Уральск : Фирма Сервер +. — 2014. — № 8 (87). C. $187-193$.

9. Бегунов А.А. Метрологическое обеспечение производства пищевой продукции [Текст] / А.А. Бегунов. - Санкт-Петербург : «Издатель», 1992 г. — 288c.

10. Митропольский А.К. Техника статистических вычислений [Текст] / А.К. Митропольский. — Москва : «Нау-ка», 1971. — 576 с. 